Original Russian Text (C) 2020 D.V. Ershov, E.N. Sochilova published in Forest Science Issues Vol. 3, No. 4, pp. 1-8

DOI 10.31509/2658-607x-2021411b7

\title{
ASSESSMENT OF DIRECT PYROGENIC CARBON EMISSIONS IN RUSSIAN FORESTS FOR 2020 USING REMOTE MONITORING DATA
}

\author{
D.V. Ershov *, E.N. Sochilova \\ Center for Forest Ecology and Productivity of the RAS, \\ Profsoyuznaya st. 84/32 bldg. 14, Moscow 117997, Russian Federation \\ *E-mail: dvershov67@gmail.com
}

Received: 14.12 .2020

Accepted: 12.27.2020

The paper presents the results of assessing pyrogenic emissions of carbon compounds in Russian forests for 2020 using remote monitoring methods. The area of forests damaged by fires was $6.5 \mathrm{mln}$ ha, whereas the amount of carbon emissions was $36.5 \mathrm{MtC}$. Although the total area of damage is higher than the average annual values, the amount of pyrogenic carbon emissions is lower than the average annual ones. In absolute terms, the year corresponds to 2016 . We registered an increase in annual carbon emissions from fires since the abnormal 2012. A preliminary analysis of the entire observation period for fires suggests that 2021 may be the next abnormal year after the years of 2003 and 2012 in terms of forest fires and direct pyrogenic carbon emissions into the atmosphere.

Key words: forest fires, pyrogenic emissions, carbon, remote monitoring, forest fuel load

Estimates of direct annual emissions of carbon dioxide $\left(\mathrm{CO}_{2}\right)$ and other greenhouse gases (GHG) to the atmosphere from forest fires are needed to calculate the carbon budget in forests. Many current approaches use the results of the analysis of burned forested areas and data on the pre-fire stock volume of forest fuel load (FFL) biomass for modelling of pyrogenic carbon emissions (Kasischke, Bruhwiler, 2002; Isaev et al., 2002; Rinsland et al., 2007; Junpen et al., 2011; Dolman et al., 2012; Zamolodchikov et al., 2017). The method developed at the CEPF RAS and modified by the authors in different years provides for the calculation of the stock volume of the main burn conductors of FFL before the fire (Sochilova et al., 2009). Further, the type and intensity of fire are determined by satellite products (Stytsenko et al., 2013), as well as the corresponding FFL consumption and the volumes of GHG (Ershov et al., 2009) emitted during combustion in the Russian forests. The data on burned areas and fire forest disturbances are formed in the IKI-Monitoring Center for Collective Use (Lupyan et al., 2019). The advantage of the method is the estimation of direct pyrogenic carbon emissions on the basis of spatial analysis of fire type maps, fire intensity and pre-fire FFL stock volumes (Isaev et al., 2002). As a result, we can estimate emitted carbon during forest fires at different spatial levels of the territory of Russia.

The method was tested on Russian forests at the national level in the period from 2006 to 2015 using the TerraNorte RLC vegetation map, pre-fire FFL stocks and burn severity 
levels of forests damaged by fires (Ershov et al., 2016). Currently, we use the developed technology for the annual assessment of direct fire carbon emissions in Russian forests based on satellite monitoring data. The latest information on fire emissions over a longterm observation period was presented at the conference Contemporary Problems ... held by RAS Space Research Institute (Ershov, 2019). According to satellite monitoring data (2002-2018), the total area of forests damaged by fires during the specified period was $78.6 \mathrm{mln}$ ha, whereas the amount of direct fire carbon emissions was 578.5 MtC.

Table 1 presents statistics on direct fire carbon and GHG emissions for 10 years from 2010 to 2019. Figure 1 shows the dynamics of damaged areas and volumes of specific carbon emissions over a ten-year period. According to satellite monitoring data, the total area of forests damaged by fires for the defined period was $51.1 \mathrm{mln}$ ha; direct fire carbon emissions amounted to $375.1 \mathrm{MtC}$. Annually, the average area of damaged forests in Russia is $5.1( \pm 2.0) \mathrm{mln}$ ha, while emissions are estimated at $37.5( \pm 12.3) \mathrm{MtC}$ per year. According to satellite monitoring data, 2020 is comparable to 2016 in terms of the area of forests damaged by fires and carbon emissions. Although the area of damaged forests exceeds the average longterm values by $1.4 \mathrm{mln}$ ha, absolute carbon emissions are less by $0.91 \mathrm{MtC}$. GHG emissions are also less than the average annual values over a ten-year period. Thus, when compared with the data obtained for the period from 2010 to 2019, the level of pyrogenic emissions in 2020 was average.

Table 1. Estimates of direct emissions of carbon and greenhouse gases from forest fires over the past 10 years of satellite observations in the territory of the Russian Federation

\begin{tabular}{|c|c|c|c|c|c|c|c|c|}
\hline \multirow{2}{*}{ Year } & \multirow{2}{*}{$\begin{array}{c}\text { Carbon } \\
\text { emissions, } \\
\text { tC }\end{array}$} & \multirow{2}{*}{$\begin{array}{c}\text { Damaged } \\
\text { area, ha }\end{array}$} & \multirow{2}{*}{$\begin{array}{c}\text { Specific C } \\
\text { emissions, } \\
\text { t/ha }\end{array}$} & \multicolumn{5}{|c|}{ Greenhouse gas emissions, $\mathrm{t}$} \\
\hline & & & & $\mathrm{CO}_{2}$ & $\mathrm{CO}$ & $\mathrm{CH}_{4}$ & $\mathrm{~N}_{2} \mathrm{O}$ & $\mathrm{NO}_{\mathrm{x}}$ \\
\hline 2010 & $15,321,461$ & $2,107,599$ & 7.27 & $56,178,690$ & $2,145,005$ & 245,143 & 1,685 & 60,914 \\
\hline 2011 & $26,770,414$ & $3,850,295$ & 6.95 & $98,158,185$ & $3,747,858$ & 428327 & 2945 & 106,432 \\
\hline 2012 & $83,821,145$ & $11,365,539$ & 7.38 & $307,344,198$ & $11,734,960$ & $1,341,138$ & 9,220 & 333,249 \\
\hline 2013 & $28,093,793$ & $3,420,556$ & 8.21 & $103,010,574$ & $3,933,131$ & 449,501 & 3090 & 111,693 \\
\hline 2014 & $35,882,796$ & $4,441,315$ & 8.08 & $131,570,251$ & $5,023,591$ & 574,125 & 3947 & 142,660 \\
\hline 2015 & $20,413,097$ & $3,691,087$ & 5.53 & $74,848,024$ & $2,857,834$ & 326,610 & 2245 & 81,157 \\
\hline 2016 & $37,188,902$ & $6,341,329$ & 5.86 & $136,359,307$ & $5,206,446$ & 595,022 & 4091 & 147,852 \\
\hline 2017 & $40,089,468$ & $3,334,361$ & 12.02 & $146,994,716$ & $5,612,526$ & 641,431 & 4,410 & 159384 \\
\hline 2018 & $43,339,633$ & $6,622,768$ & 6.54 & $158,911,988$ & $6,067,549$ & 693,434 & 4767 & 172,306 \\
\hline 2019 & $44,213,928$ & $5,904,418$ & 7.49 & $162,117,736$ & $6,189,950$ & 707,423 & 4864 & 175,782 \\
\hline Total & $375,134,637$ & $51,079,267$ & 7.34 & $1,375,493,669$ & $52,518,849$ & $6,002,154$ & 41,264 & $1,491,429$ \\
\hline $\begin{array}{l}\text { Long-term } \\
\text { average }\end{array}$ & $37,513,464$ & $5,107,927$ & 7.53 & $137,549,367$ & $5,251,885$ & 600,215 & 4,126 & 149,143 \\
\hline $\mathrm{CO}^{*}$ & $12,282,064$ & $1,960,469$ & 1.8 & $45,034,234$ & $1,719,489$ & 196,513 & 1,351 & 48830 \\
\hline 2020 & $36,603,092$ & $6,465,819$ & 5.66 & $134,211,337$ & $5,124,433$ & 585,649 & 4026 & 145,523 \\
\hline $\begin{array}{l}\text { Relative to } \\
\text { average } \\
\text { long-term } \\
\text { values }\end{array}$ & $-910,372$ & $+1,357,892$ & -1.68 & $-3,338,030$ & $-127,452$ & $-14,566$ & -100 & $-3,619$ \\
\hline
\end{tabular}

* the average deviation is calculated in accordance with the formula $C O=\frac{1}{n} \sum(x-\bar{x})$, where $\mathrm{x}$ is the annual value of the parameter (carbon and greenhouse gas emissions); $\bar{x}$ is the average value of the parameter for $n(10)$ years. 
The analysis of the entire time series of pyrogenic carbon emissions in the period from 2002 to 2020 gave interesting results (Fig. 2). We registered two anomalous years, namely 2003 and 2012, in which the absolute pyrogenic emissions were 127.1 $\mathrm{MtC}$ and 83.8 $\mathrm{MtC}$, respectively. The time interval between the two anomalous years is 9 years. Probably, 2021 may turn out to be the next extraordinary or anomalous year in terms of fires and the scale of pyrogenic carbon emissions in Russia, since there have been no anomalous years since 2012The second important conclusion that can be drawn from the analysis of the results obtained is that the areas of damaged forests and the intensity of direct pyrogenic carbon emissions after 2012 increased by 1.4 times. Until 2012, the average area of damaged forests and carbon emissions amounted to $3.95 \mathrm{mln}$ ha and 29.2 $\mathrm{MtC}$, whereas over the past 9 years they amounted to $5.7 \mathrm{mln}$ ha and $41.1 \mathrm{MtC}$, respectively. As a result, carbon emissions from 2003 to 2011 (9 years) are comparable to carbon emissions from fires from 2012 to 2018 (7 years).

A spatial analysis of the obtained estimates of carbon emissions from fires in Russia in 2020 (Fig. 3) shows that the main contribution is made by Uralian (KhantyMansi and Yamalo-Nenets autonomous areas), Siberian (Tomsk region, Krasnoyarsk territory, and Irkutsk region), and Far Eastern regions (Republic of Sakha (Yakutia), TransBaikal territory, and Amur region).

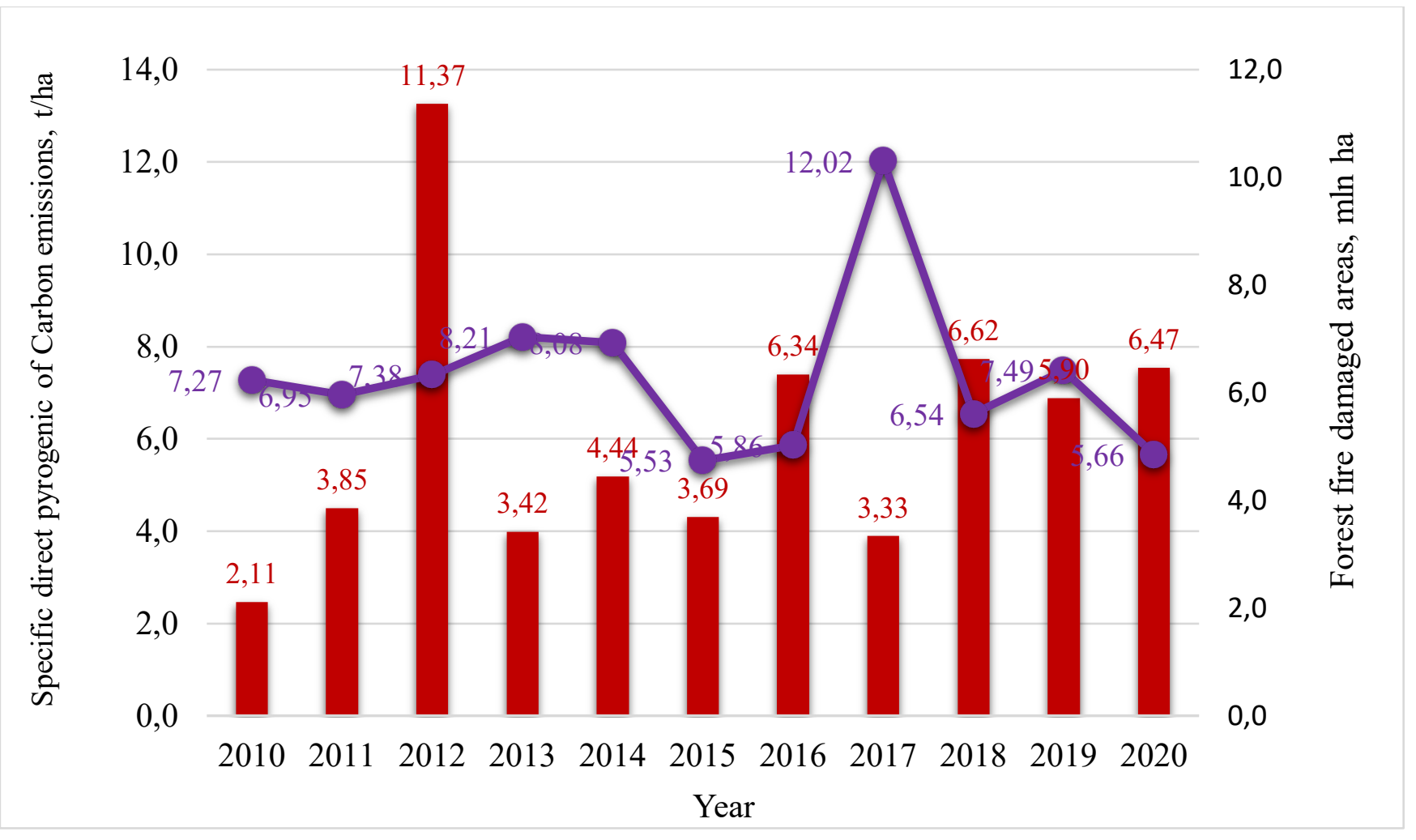

Figure 1. Dynamics of areas damaged by forest fires and specific direct pyrogenic carbon emissions (2010-2020) 


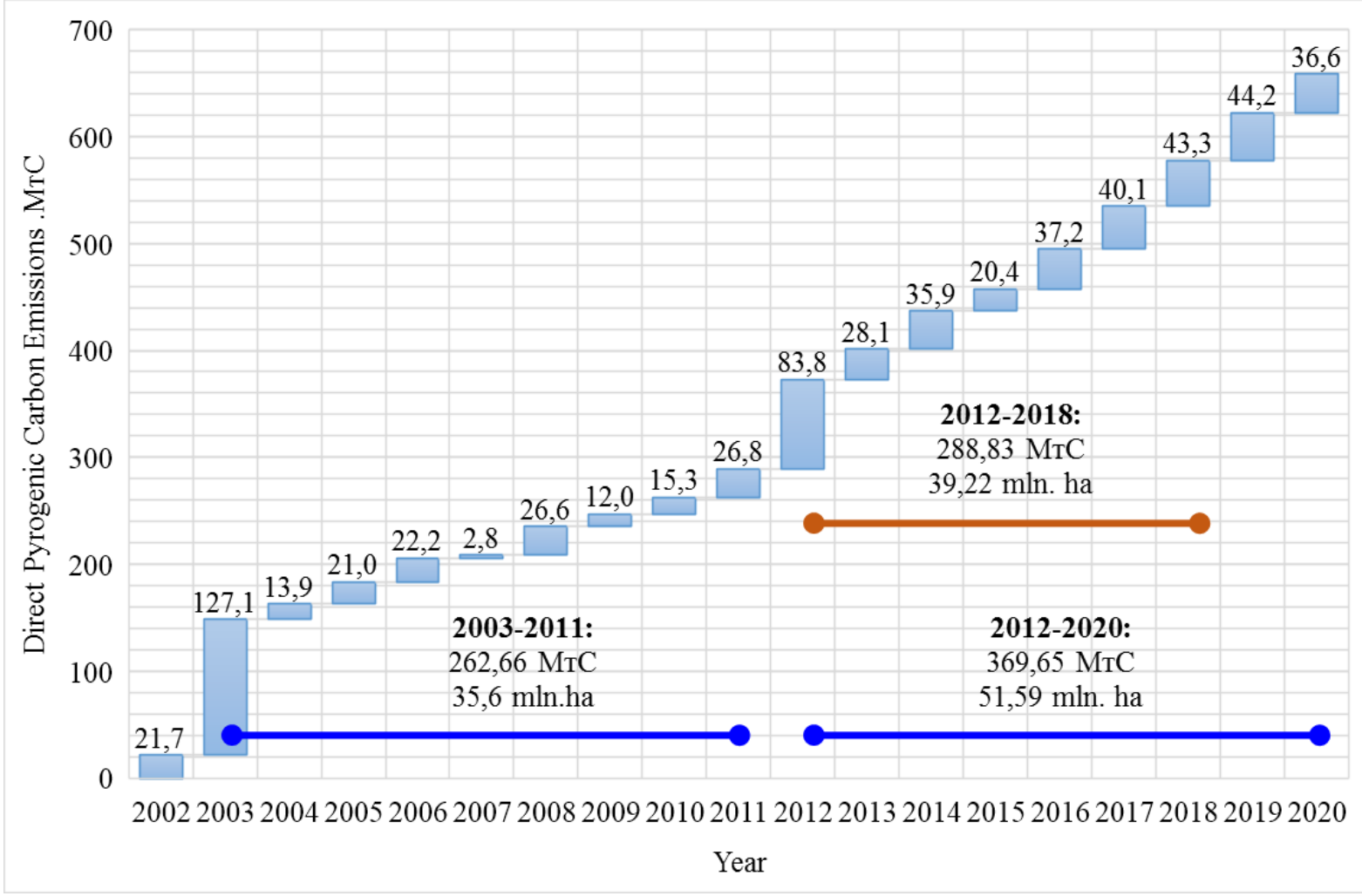

Figure 2. Dynamics of annual carbon emissions from fires during 2002-2020

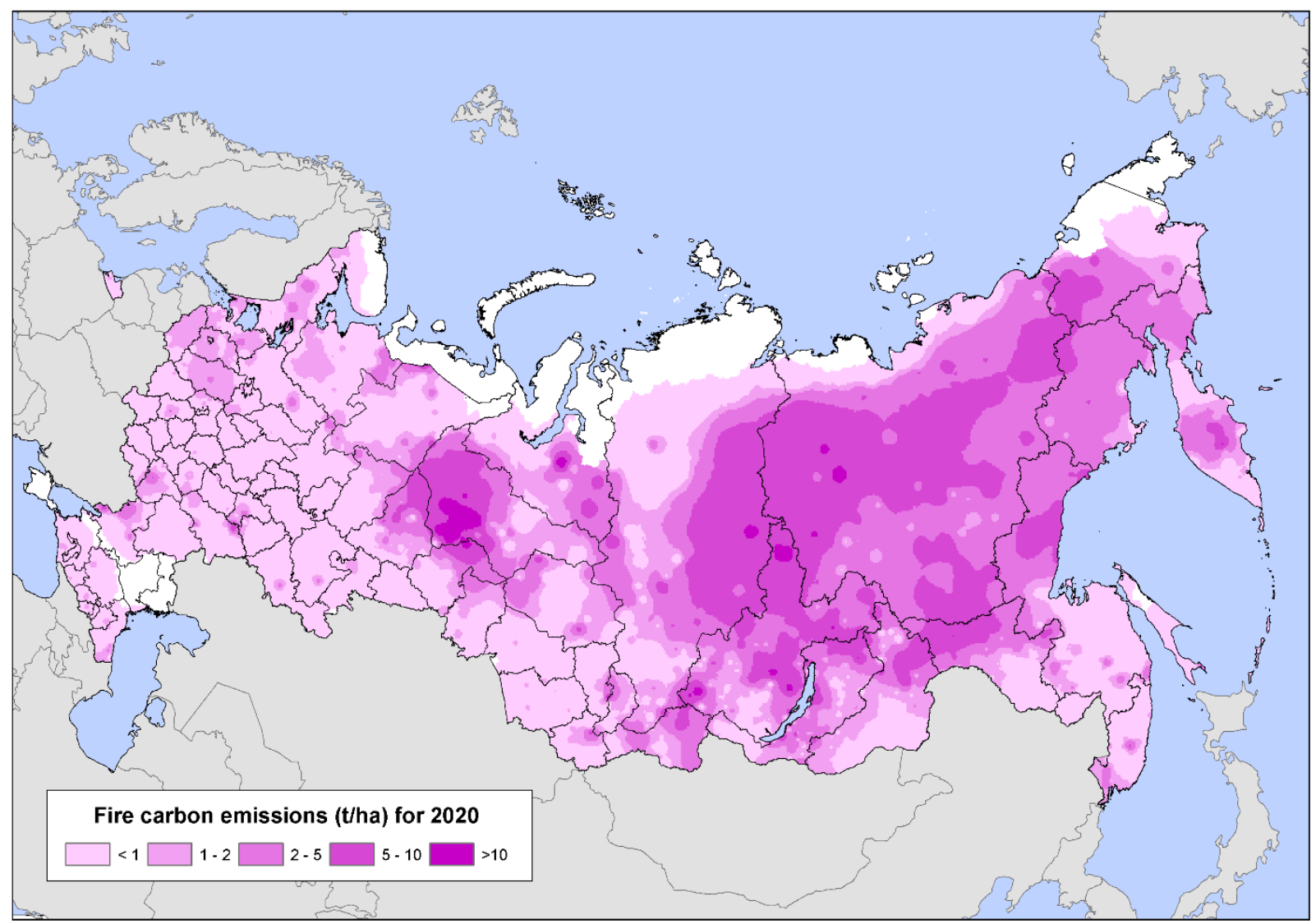

Figure 3. Map of distribution of direct specific fire carbon emissions ( $t / h a)$ in Russian forests in 2020 
Figure 4 shows the deviation of the specific pyrogenic carbon emissions in 2020 relative to the long-term average values.

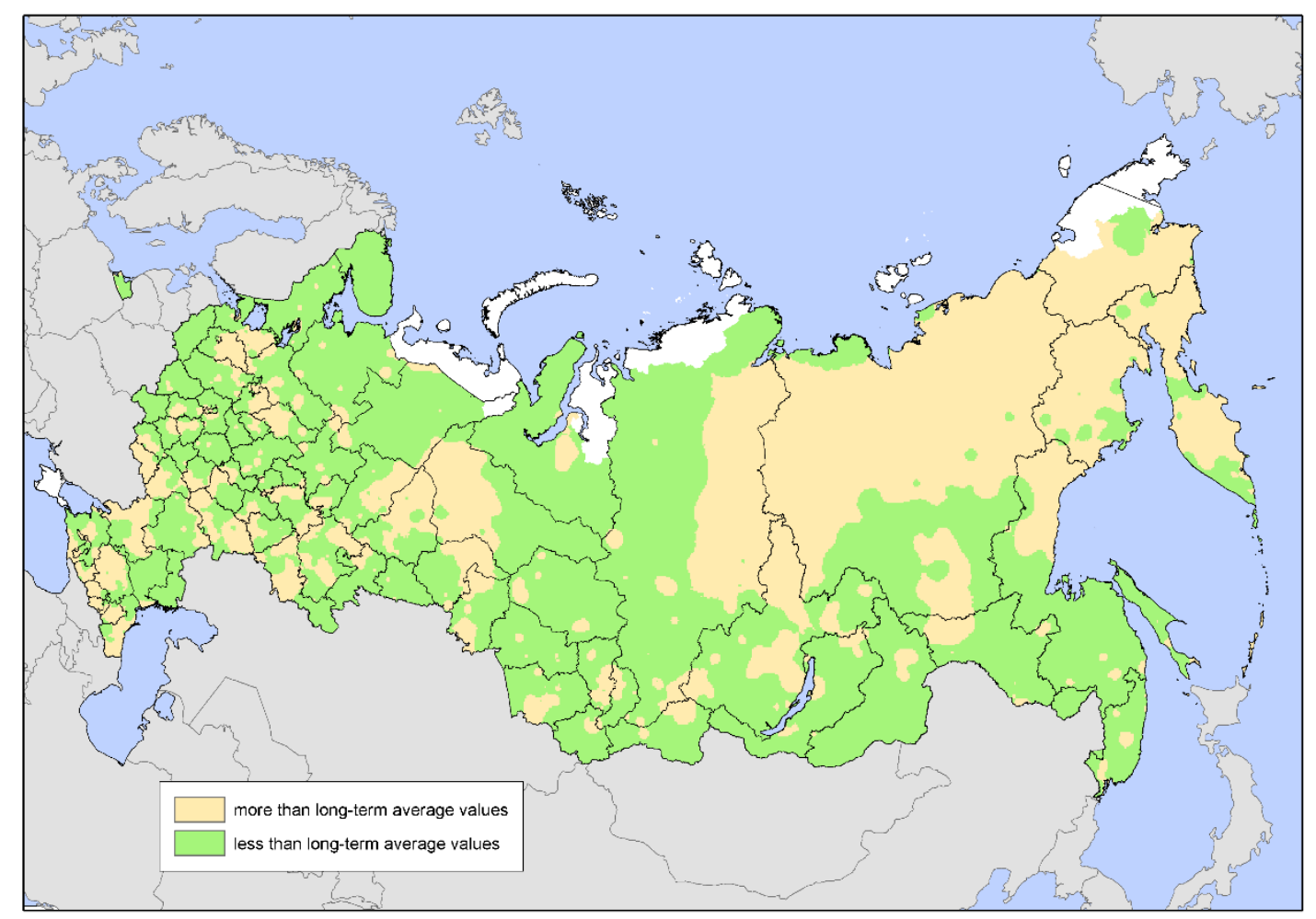

Figure 4. Map of deviations of direct pyrogenic carbon emissions in 2020 from averaged long-term values

In 2020, an excess of carbon emissions relative to long-term average values was observed in the forests of the western part of the Khanty-Mansiysk region, the northern part of the Perm territory and the Sverdlovsk region, the eastern part of the Krasnoyarsk territory, the northern and central regions of the Irkutsk Region and Yakutia, in the north of the Khabarovsk Territory and in most of the Magadan region, as well as on the forest lands of the Chukotka lands, and Kamchatka region. In the European part of Russia there are some local and fragmentary cases of a slight increase in carbon emissions over the long-term average values.

\section{Conclusion}

According to the estimates, in 2020 carbon emissions from forest fires in Russia amounted to $36.5 \mathrm{MtC}$. Although the area of damaged forests was $1.4 \mathrm{mln}$ ha larger than the average annual values whereas pyrogenic carbon emissions were lower than the average annual values and corresponded in absolute values to 2016. We registered a 1.4-fold increase in annual direct carbon emissions from fires since 2012. In terms of carbon emissions from fires in Russia, the period from 2012 to 2018 (7 years) was comparable to the period from 2003 to 2011 (9 years). A preliminary analysis of the entire observation period for fires suggests that the anomalous year of 2021 may be ranked after 2003 and 2012 in terms of forest fires and direct pyrogenic carbon emissions, comparable with 2003 and 2012 in terms of forest damage.

\section{ACKNOWLEDGEMENTS}

Pyrogenic carbon emissions were statistically assessed within the framework of the state assignment of the CEPF RAS AAAA-A18-118052590019-7; remote monitoring data and geoinformation maps were processed with the support of the Russian Science Foundation (project No. 1977-30015). 


\section{REFERENCES}

Dolman A.J., Shvidenko A., Schepaschenko D., Ciais P., Tchebakova N., Chen T., van der Molen M.K., L. Belelli Marchesini, Maximov T.C., Maksyutov S., Schulze E.D., An estimate of the terrestrial carbon budget of Russia using inventory-based, eddy covariance and inversion methods, Biogeosciences, 2012, Vol. 9, pp. 53235340.

Ershov D.V., Ocenka jemissij ugleroda ot pozharov $\mathrm{V}$ lesah Rossii na osnove rezul'tatov sputnikovogo monitoring (Assessment of carbon emissions from fires in Russian forests based on satellite monitoring), Sovremennye problemy distancionnogo zondirovanija Zemli iz kosmosa (Modern Problems of Remote Sensing of the Earth from Space), 17th All-Russian Open Conference, Space Research Institute of the RAS, 2019, p. 519.

Ershov D.V., Bartalev S.A., Isaev A.S., Sochilova E.N., Stycenko F.V., Metod ocenki pozharnyh jemissij parnikovyh gazov s ispol'zovaniem sputnikovyh dannyh: rezul'taty primenenija dlja lesov Rossii v 21 veke (Fire assessment method of greenhouse gas emission with satellite data: results of forest for Russia in the 21 st century), Ajerokosmicheskie metody $i$ geoinformacionnye tehnologii $v$ lesovedenii, lesnom hozjajstve $i$ jekologii (Aerospace Methods and GISTechnologies in Forestry, Forest Management and Ecology), Proceedings of the VI All-Russian Conference, Moscow, Russia, April 20-22, 2016, pp. 12-17.

Ershov D.V., Kovganko K.A., Sochilova E.N., GIS-tehnologija ocenki pirogennyh jemissij ugleroda po dannym TerraMODIS i gosudarstvennogo ucheta lesov (GIS-technology of fire carbon emission assessment using Terra-Modis products and state forest account data), Sovremennye problemy distancionnogo zondirovanija Zemli iz kosmosa, 2009, Issue 6, Vol. 2, pp. 365-372.

Isaev A.S., Korovin G.N., Bartalev S.A., Ershov D.V., Janetos A., Kasishke E., Sugart H., FrenchN., OrlickB., Murphy
T., Using remote sensing for assessment of forest wildfire carbon emissions, Climate Change, 2002, Vol. 55, pp. 235-249.

Junpen A., Garivait S., Bonnet S., Pongpullponsak A., Spatial and Temporal Distribution of Forest Fire PM10 Emission Estimation by Using Remote Sensing Information, International Journal of Environmental Science and Development, 2011, Vol. 2. No. 2, pp.156-161.

Kasischke E.S., Bruhwiler L.P., Emissions of carbon dioxide, carbon monoxide, and methane from boreal forest fires in 1998, $J$. Geophys. Res., 2002, Vol. 107, p. 8146.

Loupian E.A., Proshin A.A., Bourtsev M.A., Kashnitskii A.V., Balashov I.V., Bartalev S.A., Konstantinova A.M., Kobets D.A., Mazurov A.A., Marchenkov V.V., Matveev A.M., Radchenko M.V., Sychugov I.G., Tolpin V.A., Uvarov I.A., Opyt jekspluatacii i razvitija centra kollektivnogo pol'zovanija sistemami arhivacii, obrabotki i analiza sputnikovyh dannyh (CKP «IKI-Monitoring») (Experience of development and operation of the IKI-Monitoring center for collective use of systems for archiving, processing and analyzing satellite data), Sovremennye problemy distancionnogo zondirovanija Zemli iz kosmosa, 2019, Vol. 16, No. 3, pp. 151-170.

Rinsland C.P., Goldman A., Hannigan J.W., Wood S.W., Chiou, L.S., Mahieu E., Longterm trends of tropospheric carbon monoxide and hydrogen cyanide from analysis of high resolution infrared solar spectra, J. Quant. Spectrosc. Ra., 2007, Vol. 104, pp. 40-51.

Sochilova E.N., Ershov D.V., Korovin G.N., Metody sozdanija kart zapasov lesnyh gorjuchih materialov nizkogo prostranstvennogo razreshenija (Methods of course resolution forest fuel load mapping), Sovremennye problemy distancionnogo zondirovanija Zemli iz kosmosa, 2009, Issue 6, Vol. 2, pp. 441-449.

Stytsenko F.V., Bartalev S.A., Egorov V.A., Loupian E.A., Metod ocenki stepeni povrezhdenija lesov pozharami na osnove sputnikovyh dannyh MODIS (Post-fire forest tree mortality assessment method 
using MODIS satellite data), Sovremennye problemy distancionnogo zondirovanija Zemli iz kosmosa, 2013, Vol. 10, No. 1, pp. 254-266.

Zamolodchikov D.G., Grabovsky V.I.,

Shulyak P.P., Chestnykh O.V.,
Sovremennoe sokrashhenie stoka ugleroda V lesa Rossii (Recent decrease of carbon sink to Russian forests), Doklady Akademii nauk, 2017, Vol. 476, No. 6, pp. 719-721.

Reviewer: PhD in agriculture, Deputy Research Director of RAS Forest Research Institute of Karelian Research Centre S.A. Moshnikov 